Session 2221

\title{
ELECTRONIC PROJECT DELIVERY VIA STUDENT GENERATED WEB SITES "LESSONS LEARNED"
}

\author{
Charles McIntyre and Hung Nguyen \\ Civil Engineering and Construction \\ North Dakota State University
}

Introduction

In traditional "project-based" courses (senior level design and capstone courses), the final products are typically paper-based reports and plans (CAD drawings) which include information related to the design and construction aspects of the project. On occasion, the final projects are submitted in some form of electronic format (CD, zip, etc.) [2,5]. Currently, many engineering and construction firms post project information on company or project specific web sites. In order to provide students with the "real world" experience of posting information electronically, the logical decision would be to require students to mimic the industry practices. The contents of this paper, 1.) documents the traditional and revised course delivery system for CME 430 Land Development, 2.) provides an overview of the mechanisms for evaluation and assessment, 3.) explains some of the tools and techniques that have been developed at NDSU to assist students with web page development, 4.) provides student outcome data for a 3-year period, 5.) offers an analysis of the data, and 6.) formulates some recommendations and conclusions.

\section{Course Overview}

CME 430 - Land Development is a 16-week, fall semester, 3-credit, senior-level engineering and management course consisting of 40 - 50 students. Students are placed in permanent groups of 4 or 5 students and are required to develop engineering site plans and associated project documents for an existing undeveloped local parcel of land. Students develop a market research report, conduct a site visit, construct site layout plans (roads, lots, and all infrastructure), develop cost estimates, and a financing plan which are submitted as interim paper-based reports throughout the semester. The final deliverable is a paper-based project report including all plans and drawings. The Blackboard course management system is used extensively in the course to post project information and communicate with student groups. Approximately one-half the class time is dedicated to modified lecture-based presentations (incorporating aspects of problembased learning) with the other half used for site visits, guest speakers, and in-class worksessions. There are no exams or quizzes. Grades are based solely on the interim reports (assignments) and final project report. 


\section{Course Grading and Assessment}

During the 2001 and 2002 fall semesters, student evaluation and grading was done by solely the instructor. Peer evaluation of group work was conducted using a paper-based form which evaluated the contribution of other team members. Assessment included the standard NDSU Student Rating of Instruction (SROI) form, as well as, an additional paper-based form, created by the instructor which requested student feedback concerning the course delivery, perceived student learning, and evaluation methods [3].

During the 2003 Fall Semester, a different philosophy for student submissions was implemented. All student submissions (interim and final reports) would be conducted electronically through the use of student developed web pages. Company and personnel information (names, titles, qualifications, contact information, etc.) was also required on each group web site, similar to what most businesses have in place.

Grading of the interim reports and the final project was also conducted electronically and was performed by the course instructor. Completed grading sheets were sent electronically to group members (electronic forms). In addition, much of the communication between the instructor and the student groups was also in electronic format (email). Additional feedback in the form of written comments sent electronically to each group (via email) was conducted by industry project participants, i.e., the Industry Advisory Team (IAT). The IAT consisted of local land developers, each of whom have specialized areas of expertise, and the Senior Planner for the City of Fargo, as shown in Table 1. The primary functions of the IAT were to serve as guest lecturers and as project reviewers based on their area or expertise.

\begin{tabular}{|l|l|l|}
\hline \multicolumn{3}{|c|}{ Table1. Industry Advisory Team (IAT) } \\
\hline \multicolumn{1}{|c|}{ Name } & \multicolumn{1}{|c|}{ Affiliation } & \multicolumn{1}{c|}{ Areas of Expertise } \\
\hline Ace Brandt & Brandt Holdings & design and marketing \\
\hline Richard Burns & Richard Burns \& Associates & infrastructure and project management \\
\hline Don Kounovski & Kounovski Properties & cost estimating and scheduling \\
\hline Cindy Gray & City of Fargo & planning and regulations \\
\hline
\end{tabular}

The overall objective was to simulate current industry practices concerning electronic documentation and information exchange. However, the initial "problem" presented to the student groups was the creation of a group web page. The students were provided with some support mechanisms, as described in the next section. During the summer of 2003, the instructor worked with the Information Technology Services (ITS) at NDSU to develop some of the tools that are needed to create student web pages. 
Support Mechanisms for Web Page Development

At NDSU, ITS has developed the "Sponge" web site that assists faculty and students with using the tools of technology (http://www.ndsu.nodak.edu/sponge/). Sponge is a site that includes step-by-step information on how to complete technology tasks and projects. It offers instructions on common software and hardware that is available to students, faculty, and staff at the Technology Learning Center (TLC) and the Industrial Agricultural Communication Center (IACC) Service Center. The Sponge site includes "how-to" instructions on a variety of topics, including: 1.) publications (creating a newsletter, brochure, booklet, etc.), using iMovie (create, import, and export movies), creating a CD, PowerPoint (basic and advance features), and web design (using Dreamweaver). The author was involved with the creation of web page templates that could be used by student groups to simplify the process of web page development. In addition the Department of Construction Management and Engineering (CME) at NDSU purchased several copies of Dreamweaver that were installed in the CME student computer cluster (20 workstations).

\section{Student Deliverables}

The overall project consisted of five (5) parcels of undeveloped land of approximately 160 acres each. Student groups were allowed to select the "best" site based on their market research and their "vision" of what they wanted to with regard to a residential and/or commercial land development project. The interim reports for the project consisted of six (6) assignments and a final project, as listed in Table 2.

\begin{tabular}{|l|l|}
\hline \multicolumn{2}{|c|}{ Table 2. Student Deliverables } \\
\hline Assignment No. 1 & Market Research Report \\
\hline Assignment No. 2 & Site Visit and Analysis \\
\hline Assignment No. 3 & Conceptual Plan \\
\hline Assignment No. 4 & Conceptual Design for the Sanitary Sewer and the Water System \\
\hline Assignment No. 5 & Storm Water Management System \\
\hline Assignment No. 6 & Cost Estimate and Financial Analysis \\
\hline Final Project & Final Project \\
\hline
\end{tabular}

\section{Student Outcome Data}

Table 3 presents the deliverables (assignments) and group grades for each deliverable from 2001 to 2003. The point value for certain assignments changed for certain years, but each value was normalized in terms of a percentage (\%) to allow for comparisons. 


\begin{tabular}{|l|c|c|c|c|c|c|c|c|c|}
\hline \multicolumn{7}{|c|}{ Table 3. Assignment and Group Grades (2001 - 2003) } \\
\hline & \multicolumn{3}{|c|}{2001} & \multicolumn{3}{|c|}{2002} & \multicolumn{3}{c|}{2003} \\
\hline Assignment & $\begin{array}{c}\text { Point } \\
\text { Value }\end{array}$ & $\begin{array}{c}\text { Avg. } \\
\text { Group } \\
\text { Grade }\end{array}$ & $\%$ & $\begin{array}{c}\text { Point } \\
\text { Value }\end{array}$ & $\begin{array}{c}\text { Avg. } \\
\text { Group } \\
\text { Grade }\end{array}$ & $\%$ & $\begin{array}{c}\text { Point } \\
\text { Value }\end{array}$ & $\begin{array}{c}\text { Avg. } \\
\text { Group } \\
\text { Grade }\end{array}$ & $\%$ \\
\hline 1. Market Research Report & 25 & 21.2 & 84.8 & 25 & 20.5 & 82 & 25 & 21.3 & 85.2 \\
\hline 2. Site Visit and Analysis & 15 & 10.6 & 70.7 & 10 & 7.6 & 76 & 25 & 21.9 & 87.6 \\
\hline 3. Conceptual Plan & 20 & 15 & 75 & 25 & 21 & 84 & 30 & 29.6 & 98.7 \\
\hline 4. Water \& Sewer Design & 15 & 13.2 & 88 & 20 & 18.5 & 92.5 & 25 & 23 & 92 \\
\hline 5. Storm Water Design & 15 & 13.5 & 90 & 20 & 17.7 & 88.5 & 20 & 17.8 & 89 \\
\hline 6. Cost \& Financing & 15 & 9.83 & 65.5 & 25 & 20.5 & 82 & 25 & 21.8 & 87.2 \\
\hline Final Project & 100 & 93 & 93 & 100 & 93.4 & 93.4 & 100 & 94.3 & 94.3 \\
\hline
\end{tabular}

Figure 1 illustrates a graphical comparison of the average group grades (as a \%) for each of the six (6) assignments from 2001 through 2003. Figure 2 shows the average final project group grade and the average individual course grade from 2001 through 2003.

Figure 1. Grade Comparisons (2001-2003)

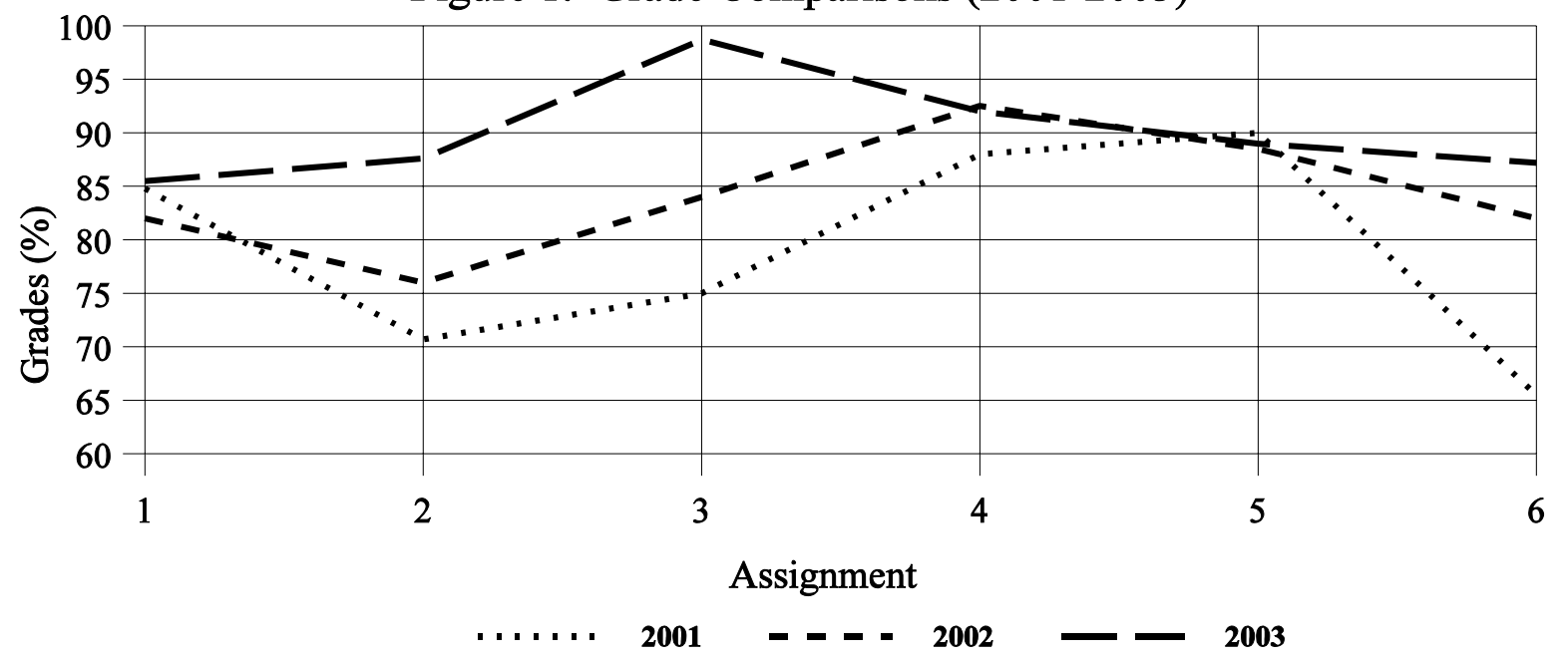

Proceedings of the 2004 American Society for Engineering Education Annual Conference \& Exposition Copyright $\odot 2004$ American Society for Engineering Education 
Figure 2 Final Project and Course Grades

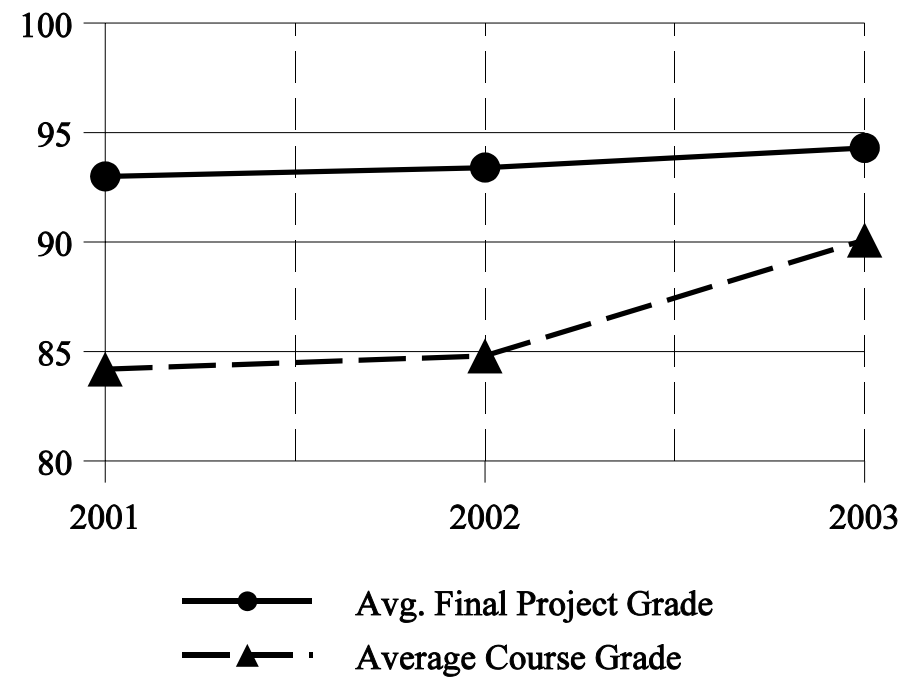

In anticipation of a change in course delivery, the instructor began collecting data (in 2002) related to the time allocated for grading each assignment and the final project. Table 4 shows the total time the instructor spent on grading. The average time per group was calculated by simply dividing the total time by the number of groups. No data is available for 2001 . Table 5, on the following page, presents the time differential (in minutes) for the average grading time per group.

\begin{tabular}{|c|c|c|c|c|c|}
\hline \multirow[b]{2}{*}{ Assignment } & \multirow[t]{2}{*}{2001} & \multicolumn{2}{|c|}{2002 (10 groups) } & \multicolumn{2}{|c|}{2003 (9 groups) } \\
\hline & & $\begin{array}{l}\text { Total Time } \\
\quad(\mathrm{hrs})\end{array}$ & $\begin{array}{c}\text { Avg Time per Group } \\
(\min )\end{array}$ & $\begin{array}{l}\text { Total Time } \\
\quad(\mathrm{hrs})\end{array}$ & $\begin{array}{c}\text { Avg Time per Group } \\
(\min )\end{array}$ \\
\hline 1. Market Research & N/A & 6 & 36 & 8 & 53.3 \\
\hline 2. Site Visit \& Analysis & N/A & 3 & 18 & 6 & 40 \\
\hline 3. Conceptual Plan & N/A & 6 & 36 & 3 & 20 \\
\hline 4. Water \& Sewer & N/A & 7 & 42 & 5 & 33.3 \\
\hline 5. Storm Water & N/A & 4 & 24 & 3 & 20 \\
\hline 6. Cost \& Financing & N/A & 4 & 24 & 3 & 20 \\
\hline Final Project & N/A & 8 & 48 & 4 & 26.7 \\
\hline
\end{tabular}

Proceedings of the 2004 American Society for Engineering Education Annual Conference \& Exposition Copyright () 2004 American Society for Engineering Education 


\begin{tabular}{|l|c|c|c|}
\hline \multicolumn{4}{|c|}{ Table 5. Average "Grading Time" per Group } \\
\hline Assignment & 2002 & 2003 & Difference \\
\hline 1. Market Research & 36 & 53.3 & 17.3 \\
\hline 2. Site Visit \& Analysis & 18 & 40 & 22 \\
\hline 3. Conceptual Plan & 36 & 20 & -16 \\
\hline 4. Water \& Sewer & 42 & 33.3 & -8.7 \\
\hline 5. Storm Water & 24 & 20 & -4 \\
\hline 6. Cost \& Financing & 24 & 20 & -4 \\
\hline Final Project & 48 & 26.7 & -21.3 \\
\hline
\end{tabular}

\section{Data Summary}

From the previous tables and figures, the it can be seen that there was not a substantial change in the grades for Assignments 1, 4, and 5 ( Market Research, Water \& Sewer and Storm Water) from 2001 through 2003. There was a significant increase in the grades for Assignments 2, 3, and 6 (Site Visit \& Analysis, Conceptual Plan, and Cost \& Financing). There was a slight increase in the average final project grade over the three-year period. The average course grade increased significantly from 2002 to 2003. The average grading time from 2002 to 2003 increased (by approximately 20 minutes) for Assignments 1 and 2, but decreased for Assignments 3 through 6 and for the Final Project.

\section{Conclusions}

The instructor has concluded that it takes longer to grade a electronic web page submissions than a traditional paper-based submission, as shown in Table 5 for Assignment 1 and 2. There are several reasons, 1.) it just takes longer to access, view (scroll), and read from the screen than it does on paper, 2.) all comments are typed and sent via email to the student groups (instead of hand written or "red-lined" on paper), and 3.) evaluation "on-line" is new territory for most instructors so there is a learning curve that accompanies this endeavor.

So, why the decrease in grading times for all other assignments? After submitting Assignment 2, the URL's for each group were posted on the Blackboard course site. Prior to this time no groups had access to other group sites. At this point in time, the competitive spirit of the groups emerged. For Assignment 3 (Conceptual Plan) each group tried to outdo each other. They also relied more on the IAT for comments and feedback prior to the submission deadline. As a result, the quality of Assignment 3 was much higher than in previous years. All of these factors contributed to "easy" grading for the instructor. Higher quality work is much easier to grade than lower quality work. This was also true for Assignment 6 (Cost \& Financing). For Assignments 4 and 5 (Water \& Sewer and Storm Water) there was not a significant increase in 
the average grade, however, the presentation of the material (format and organization) was much better than in previous years, which made the grading much less time consuming. Based on the feedback from students on the course assessment form, many individuals wrote statements, such as, "...someone is actually going to see our work," or "...we have to do a good job because we sent our web address to some potential employers." Many others stated that everyone in the group actually read and reviewed all of the material on the web site before the due date so that changes could be made. They also made the comment that they rarely did this for paper-based submissions.

From the viewpoint of the instructor, it is much easier and to grade paper-based project, however, this may be due to a lack of experience by the instructor in "on-screen" grading. But there is no question that the quality (in general) for all of the assignments and the final project did increase.

\section{Recommendations}

Before embarking on a full-scale student web page delivery system, it is recommended that the proper support mechanisms and infrastructure be in place (computer software, infrastructure, server/storage space, and web instructional support). The course instructor spent six months preparing for this change in course delivery, including running a "test case" in another course where student groups had to develop a simple web page for submitting a single assignment. An incremental approach is recommended. This type of delivery system seems to work best when the instructional content of the course is focused on active or problem-based learning. $[1,4,6]$. The PBL approach has been used in the Land Development course for four years and students view web site creation as just additional research and another problem to be solved, similar to what they do for all the assignments.

For reliable comparisons and for assessment purposes, it is recommended that data be collected for pre and post course changes. In addition, assessment data must be collected and analyzed. For this course, student response is collected not only for the course, in general, but for many of the course specifics. For example, each group writes a one page assessment of the NDSU Sponge site (with recommended changes). This information was shared with ITS personnel.

\section{Summary}

Changing the way students submit course deliverables, from paper-based to electronic, may increase the quality of the deliverables, but may also increase the time faculty devoted to grading the deliverables. There is also an increased commitment of faculty time to become somewhat familiar with web page development, as well as, an increase in class time devoted to web page instruction. Based on senior-level student comments, this is the preferred method of submitting assignments when working with groups, and it is what the industry uses today to communicate project information. 
Bibliography

[1] Allen, D., Introduction to Problem-Based Learning (PBL), a workshop organized by the Faculty Institute for Excellence in Learning, August 21, 2001.

[2] Frances, C., Pumerantz, R., and Caplan, J. "Planning for Instructional Technology: What you thought you knew could lead you astray," Change, 1999.

[3] McIntyre, C. “Assessing Problem-Based Learning in an Engineering Course," Proceedings of the 2002 ASEE North Midwest Section Annual Conference, Madison, WI (October 2002).

[4] McIntyre, C. "Problem-Based Learning Applied to the Construction Engineering Capstone at North Dakota State University," Proceedings of the 2002 ASEE National Conference, Montreal, Quebec, Canada (June 2002).

[5] Rhem, J. "Emerging Trends in College Teaching for the 21 st Century," The National Teaching and Learning Forum, 1994.

[6] Smith, K.A., Johnson, D.W. and Johnson, R.T. "Cooperative Learning and Positive Changes in Higher Education, Goodsell, Mahler, et. al. (editors), 1992.

\section{Biographies}

Charles McIntyre is an Associate Professor in Construction Management and Engineering and currently conducts research primarily in the area of teaching methodologies and assessment. He teaches courses in project scheduling, land development and risk management. Dr. McIntyre has received several awards for teaching including the Odney Award for Excellent In Teaching in 2002 and the Peltier Award for Innovative Teaching in 2003.

Hung Nguyen, is an Assistant Professor in Construction Management and Engineering and teaches courses in building construction, structures, and concrete design. Dr. Nguyen has experience as a research engineer (in Canada) and an architectural designer as well as construction supervisor. 